\title{
The Adoption of Risk Based Audit Approach in the Independent Audit Firms: A Study of Case of Vietnam
}

\author{
Thi Tam LE*, Thi Mai Anh NGUYEN ${ }^{* *}$
}

Received: November 17, 2019 Revised: December 11, 2019 Accepted: December 18, 2019

\begin{abstract}
This study was conducted to examine how independent audit firms in Vietnam understand and use risk based audit approach (RBAA) in audit practice. To answer the research questions, the researchers used primary and secondary data collected from 2018 to 2019 . The results from the interview survey showed that audit firms were aware of the advantages of adopting RBAA. However, RBAA is practiced to a moderate extent by audit firms in Vietnam. Big 4 audit firms use RBAA more popularly than Non-Big 4 audit firms. The causes of the difference are the disadvantages of adopting RBAA and client's characteristics such as relevant guideline, audit fees, auditors' knowledge and experience. Besides, the study investigated factors impacting on the RBAA adoption by distributing a questionnaire to 246 auditors of 126 audit firms in Vietnam. A set of statistical appropriate methods where used through SPSS software version 22.0. The results indicated that there were six factors influencing RBAA adoption including: Auditor's ability, Technological development, Audit fees, auditors' motivation, Audit time and client's risk. Of which, auditor's ability and technological development are factors that have the most significant and positive impacts on the adoption of RBAA. Additional implications were argued in the final section of this study.
\end{abstract}

Keywords : Risk Based Audit Approach, Independent Audit Firm, Big Four, Vietnam

JEL Classification Code: G32, M21, M42

\section{Introduction}

When auditing financial statements, auditors may use a variety of approaches such as substantive procedures approach, balance sheet approach, systems-based approach and risk-based approach. In particular, the risk-based approach has paid much attention in both research and practice that is explained through the advantages of the approach compared to traditional approaches. On the one hand, the method meets the requirements about development trend of the current audit market (Bell, Solomon, \& Thomas, 1997; Brands, 1998; Prinsloo, 2008;

\footnotetext{
* First Author and Corresponding Author. PhD, Lecturer, Department of Accounting, Faculty of Economics and Management, Thuyloi University, Vietnam [Postal Address: No. 175, Tay Son Road, Dong Da District, Hanoi, 100000, Vietnam] Tel. +84984537282, Email: lethitam@tlu.edu.vn ** PhD, Lecturer, Department of Auditing, Faculty of Economics, Natural Resources and Environment, Hanoi University of Natural Resources and Environment, Vietnam. Email:nmanh86@gmail.com () Copyright: Korean Distribution Science Association (KODISA)

This is an Open Access article distributed under the terms of the Creative Commons Attribution NonCommercial License (https://creativecommons.org/licenses/by-nc/4.0/) which permits unrestricted noncommercial use, distribution, and reproduction in any medium, provided the original work is properly cited.
}

Sardasht \& Rashedi, 2018). On the other hand, risk based approach also helps auditors understand the entity, identify and address risks of material misstatement, ensure effectiveness and quality of the audit (Gibson, 2003; Lemon, Tatum, \& Turley, 2000; Robson, Humphery, Khalifa, \& Jones, 2007).

Although risk based audit approach (RBAA) has been hailed as an active revolution in auditing sector, there still appear some limitations of this method (Abdullah \& AlAraj, 2011). In other words, most studies about RBAA are conducted in developed countries. Meanwhile, Naibei, Oima, and Ojera (2014b) and Vilsanoiu and Serban (2010) argued that it is important to understand how RBAA is adopted in different countries. Making views on RBAA without considering the scope of the research is to ignore the multidimensional information about how auditors apply RBAA and adjust it in the future. Moreover, even within each country, there is a difference in viewpoints between small and large audit firms (Kutum, Fraser, \& Hussainey, 2015; Naibei, Oima, \& Ojera, 2014a).

Vietnam is a developing country, and the auditing profession is dominated by the Big 4 audit firms. These 
companies lead in the number of clients as well as the number of professional employees. Most of their clients are FDI enterprises and domestic enterprises with large scale. The remaining audit firms (187 firms) focus on small and medium-sized clients. Auditors of these firms slowly update new developments in the field of accounting and auditing because they have limited access to appropriate accounting and auditing documents while not being able to spend money and time on training programs. Differences in audit firms and their customers will lead to differences in opinions and uses of RBAA about audit process. Therefore, this study's objectives are to examine how independent audit firms in Vietnam understand and use the risk based audit approach and which factors impact on RBAA adoption. The aim of the study can be expressed through the following questions:

1. What are the motivations for adopting RBAA in independent audit firm in Vietnam?

2. What are the advantages and disadvantages of adopting RBAA?

3. What is the level of adopting RBAA in independent audit firm in Vietnam?

4. What factors influence the RBAA adoption in Vietnamese independent audit firm?

\section{Literature Review}

Along with the development and complexity of the economy as well as the requirements of regulators, professional organizations and community, it is expected that auditors should be more active and responsible for audit operations and results. Moreover, auditing firms are facing pressures from customers with large scale and increasing number of transactions, complex nature, and wide application of information technology. This fact leads to the need to improve auditing profession, especially audit methods. The literature generally classifies four generations of audit approaches including substantive procedures, balance sheet, systems-based, and risk-based approach (Prinsloo, 2008; Sardasht \& Rashedi, 2018).

RBAA began to be mentioned and used by major audit firms in the 1990s (Robson, Humphery, Khalifa, \& Jones, 2007). Based on this approach, business risk is determined when customers fail to achieve their goals (Arens, Elder, \& Beasley, 2008). Then, auditors focus heavily on risk analysis to define the risk of material misstatement. This includes analyzing a range of internal and external risks, in which business risks may indirectly or directly lead to the risk of material misstatement in financial statements. As a result, it provides opportunities to utilize scarce audit resources, align audit efforts with management goals, reduce risks by audit procedures that concentrate on weak audit areas (Gibson, 2003; Knechel, 2001; Lemon, Tatum, \& Turley, 2000; Mozammal, 2005; Robson, Humphery, Khalifa, \& Jones, 2007). RBAA will create significant changes in audit program and procedure (Abdullatif \& AlKhadash, 2010).

Since the introduction of risk-based auditing, there are many statements that BRA is more effective than traditional audit approaches. Peecher, Schwartz, and Solomon (2007) argued that the transition to RBAA method better meets the needs of society and the requirement of higher quality in auditing sector, especially when auditors has a good knowledge of management strategies and policies, and internal control systems of customers. Aldjaafarh (2008) explained that the RBAA concerned as one of the most modern methods used in the audits. It directs audits towards the high-risk centers and activities in banking system. Business risk audit approach operates scientifically in effort to the most dangerous zones in the enterprise, and the various stages of audits, both when building the annual management plan or establishing the audit task, the implementation stages, and conclusion. In addition, there are many reasons for using this method such as reducing audit time, because auditors pay much attention on the most important risks (Choy \& King, 2005). RBAA is enable to increase audit effectiveness and the accuracy of auditor's opinion, add values to customers, create more reliability for users of audit results (Aldjaafarh, 2008; Bell \& Solomon, 2002; Cullinan \& Sutton, 2002; Knechel, 2007; Winograd, Gerson, \& Berlin, 2000).

The studies of RBAA often concentrate on large audit firms and in developed countries such as the US and Europe (Abdullah \& Al-Araj, 2011; Lovaas, 2009; Vilsanoiu \& Serban, 2010). This research gap shows that RBAA should be investigated in both small audit firms and in developing countries. In Vietnam, the application of RBAA only has been mentioned since 2014 when the Ministry of Finance issued a new system of audit standards. This shows the importance of RBAA and raised high expectations in audit profession in future. Like many emerging economies, most audit firms in Vietnam are small and medium scale. These firms are constantly struggling to maintain operations and limited funding and time for training programs to improve auditors. Moreover, RBAA is a new approach implemented in Vietnam that there are not many accompanying documents. They are also restricted by their lack of access to appropriate literature on the application of RBAA. Many researchers found that the application of RBAA has been found in different perspectives by large and small audit firms (Nguyen \& Le, 2018).

In general, the large audit firms are commonly used and more proficient in RBAA than small firms. Non-Big Four 
has not yet mastered the RBAA in audit process as well as not thoroughly applied to all clients. From the previous literature, RBAA has not been mentioned by any in-depth study in Vietnam.

In order to perform successful audits, the use of risk business approach required auditors develop the skills to make judgments based on evidence which appear uncertainly (Curtis \& Turley, 2007; Knechel, 2007). In addition, auditors should spend a lot of time to understand the characteristics of the industry and transactions which express the internal and external relationships of client (Kutum, Fraser, \& Hussainey, 2015). Otherwise, in the development of RBAA, there are certain obstacles that need to be considered. Firstly, there is a gap between customer's expectations and the capabilities of auditors. Secondly, conflicting views are appeared around the auditor's responsibility. Thirdly, the audit results ensure reasonable reliability. Finally, the standards and regulations are applied in the audit practice (Prinsloo, 2008). It is explained that it is necessary to examine factors impacting the application of RBAA.

Allaham, Nassar, and Reesh (2017) investigated about factors affecting the implementation of RBAA in commercial banks in Jordan which has shown a significant influence of size, technological development and availability of the auditor's characteristics. Thereby, they made the recommendations behind positive relationships that the banks with more large size and the complexity of technological system faced more risks and need increase the adoption of RBAA. Besides, Nazmi, Arori, and Ibrahim (2017) found that the clarity of the concept of business risk audit and the technological development were high impact on the business risk audit. The cost of the audit process and the time were average impact on the business risk audit. The factors affecting the business risk audit significantly impact on the quality of external audit.

Abdallah, Mssadeh, and Othman (2015) measured the impact of business risk on the quality of the auditing process. By distributing a questionnaire to 325 auditors, they came up with a number of findings that there is an evidence for the regulatory risks environmental, systematic risks and occupational risks on the quality of the audit process from the perspective of the auditors. According to Naibei, Oima, and Ojera (2014a), the purpose of their study was to evaluate the extent of application of business risk among audit firms in Western Region, Kenya. Data was collected from structured questionnaire sent to 144 auditors, including 3 auditors at each of 48 audit firms. The results pointed out that RBAA was applied in moderation with mean of 3.367, SD of 0.086 . These findings provide direction for feedback on business risks among auditors, enrich an overview of audit risks and audit fees with expanded variables and evidence.

\section{Research Methodology}

Two data sources are primary and secondary data collected for research purposes. Primary data was collected using questionnaires while secondary data was collected from semi-structured research and interview documents. First, previous literature was reviewed to examine similar studies and gain an overview of the main discussions. Second, to address the first two questions, an interview of respondents including audit partners, managers and seniors from 10 audit firms in Vietnam. The authors conducted direct interviews at their workplace and they was chosen time to make them feel comfortable. The number of people interviewed in each audit firm ranges from one to four, depending on the availability of individuals. Totally, twenty-three individuals were interviewed between April and June 2018. Clients do not allow the authors to interview additional individuals that waste their time. The clients also state that all representatives are capable of giving similar and appropriate answers. The time taken to complete an interview lasts from 30 to 45 minutes. All interviews were recorded on 40 pages creating a large data to analyze the motivations to apply RBAA and explain the disadvantages and advantages of adopting RBAA between Big 4 auditing firms and Non-Big 4 firms. All interviewed individuals have experience in auditing profession sector. In particular, they know or/and understand RBAA. Respondents are guaranteed the confidentiality of the information they provide.

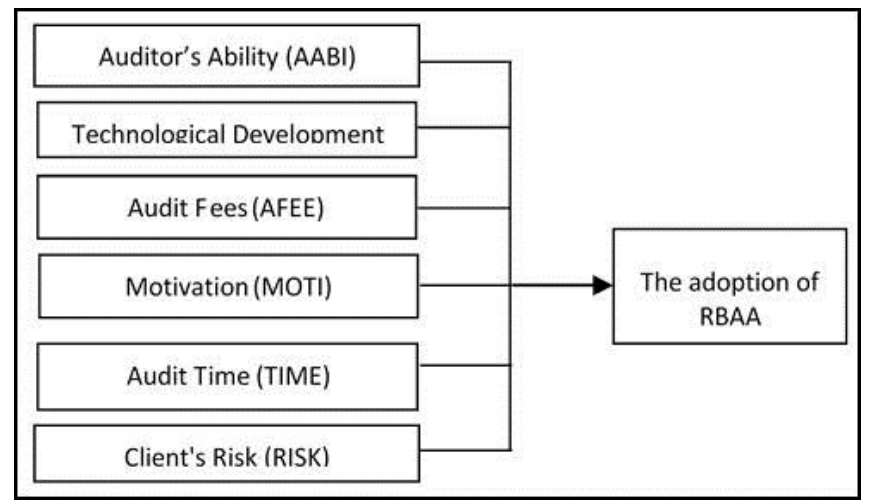

Figure 1: Research model

Thirdly, to address the last two questions, questionnaire was designed. The scales for the questionnaire are drawn from two main studies of Nazmi, Arori, and Ibrahim (2017) and Naibei, Oima, and Ojera (2014b). Official questionnaire had been distributed to a sample survey included 500 auditors who are working at 150 audit firms in Vietnam from 2018 to 2019 . They interpreted their degree of agreement and disagreement about six factors impacting 
on the application of RBAA with the use of Likert scale of five points (1-strongly disagree, 2-disagree, 3-not sure, 4agree, 5-strongly agree, 4-agree). Research model was de veloped in Figure 1.

The survey results collected 266 responses. Of which 20 invalid responses were removed, and 246 valid responses were retained which met the required sample to reach 9 $5 \%$ in the statistical results. Data analysis was conducted. The authors entered the responses into SPSS software 22.0. This software allowed us to perform descriptive statistics, independent samples T-Test, reliability analysis, factor analysis, correlation analysis, and regression analysis.

\section{Research Results}

\subsection{Results of Quality Method}

From the interview data analysis, the first part covers the key issues found, as follow:

The motivation for adopting RBAA: For the Big Four auditors, main motivation to adopt RBAA is to improve audit efficiency. The respondents highlight what auditing industry in the world was moving towards RBAA and they want to maintain the developments. Interestingly, an auditor explained that the reason why their firms adopt RBAA is that this approach gains financial benefits. Because consulting services will help customers better understand risks and define processes and ways to deal with risks. In contrast to the Big Four auditors, almost Non-Big 4 auditors explained that changes in regulations have forced them to apply RBAA and the general trend on the audit standards is to adopt more. Only a few auditors belong to this group state that the application of RBAA achieves many benefits.

The advantages of adopting RBAA: There is no difference of views between Big and Non-Big Four auditors about the advantages of RBAA. Three views are mentioned by the auditors. Firstly, RBAA enable to improve audit efficiency and quality. A lot of auditors indicate that RBAA reduces risks for themselves and their clients that lead to the performance of a higher quality audit. Secondly, RBAA makes more aware of problems and concerns with their clients. Some participants show that RBAA requires auditors to discuss and explain more what auditing firms provide to customers. As a result, they feel more knowledgeable which goes into an audit and is more prepared when talking to clients and examining clients' business environment. Thirdly, RBAA leads to increase confidence in the auditor's report by the client's management and the users of financial statements. Finally,
RBAA provides added values to the clients through giving advices on financial report, internal control and corporate governance.

The disadvantages of adopting RBAA: There are differences of views between Big and Non-Big Four auditors about the disadvantages of RBAA application. For Big Four auditors, many people interviewed show that RBAA requires senior auditors (managers and partners) to oversee the work of lower-level auditors. It is also explained that they face the risk of losing customers when expressing their opinions on auditing reports about customer weaknesses caused by business risks and internal control. Even, the interviewees who appreciated that the use of RBAA in Vietnam is highly effective and add value for clients, does not deny the existence of problems or limitations in RBAA application.

In general, most of Non-Big Four auditors report that audit fees is considered as a major issue limiting the application of RBAA. An auditor said that she spent a lot of time on the full application of risk assessment and client acceptance procedures which increase audit fees. Another auditor explained that RBAA was very costly and timeconsuming while our clients with small size do not will to pay the high fees. In addition, limitations of knowledge and experience in risk based approach, lack of tools to identify risks, lack of guidance documents and the complexity of RBAA are also considered by many participants.

\subsection{Results of Quantity Method}

\subsubsection{The Level of Adopting RBAA in Audit Practice}

Respondents were required to indicate the extent to which they carry out RBAA to deal with the first purpose. Table 1 below summarizes the level of adopting RBAA between Big 4 and Non-Big 4 firms.

Table 1: Application of RBAA in Vietnam

\begin{tabular}{|c|c|c|c|c|}
\hline \multirow{2}{*}{ Audit firm } & \multicolumn{2}{|c|}{ Big Four } & \multicolumn{2}{c|}{ Non-Big Four } \\
\cline { 2 - 5 } & Mean & $\begin{array}{c}\text { Std. } \\
\text { Deviation }\end{array}$ & Mean & $\begin{array}{c}\text { Std. } \\
\text { Deviation }\end{array}$ \\
\hline $\begin{array}{c}\text { Level of } \\
\text { adopting } \\
\text { RBAA }\end{array}$ & 4.567 & 0.086 & 2.867 & 0.046 \\
\hline
\end{tabular}

The study reveals that RBAA is practiced to a moderate extent in Vietnam. In Likert scale of five point, the average score of RBAA is 3.986 (standard deviation by 0.086). However, there are differences in the level of RBAA application between Big 4 audit firms and Non-Big 4 audit firms. While the RBAA is most prevalently practiced by Big 4 audit firms (mean: 4.567, standard deviation: 0.086), Non-Big 4 audit firms tend to apply the RBAA to a low degree (mean: 2.867, standard deviation: 0.046). The 
difference is because clients of Big 4 firms are large in size. Thus, they are ready to pay high fees to receive risk management advises. On the other hand, Big 4 audit firms have full guidelines of RBAA as well as publish working papers and explanations of how they use RBAA in practice. Moreover, their auditors applying the approach are capable, qualified and proficient when auditing clients. The full adoption of BRAA becomes obvious by the Big 4 firms. In contrary, the majority of customers in Non-Big 4 firms have poor corporate governance systems and internal control that auditors often assess the high level of control risk without control testing. Consequently, it does not reduce the audit procedures, even increase substantive testing. Auditors reveal that RBAA is designed more for large companies which is not suitable for small companies.

\subsubsection{Factors Influencing on Adopting RBAA}

This second part covers the key issues found from the primary data analysis. The steps are as follows:

Table 2: Descriptive Statistics of the respondents

\begin{tabular}{|c|c|c|c|}
\hline \multicolumn{2}{|c|}{ Item } & Frequency & Percentage \\
\hline \multirow{2}{*}{ Gender } & Male & 152 & $61.6 \%$ \\
\hline & Female & 94 & $38.4 \%$ \\
\hline \multirow{4}{*}{ Age } & $20-29$ years & 73 & $26.7 \%$ \\
\hline & $30-39$ years & 125 & $50.8 \%$ \\
\hline & $40-49$ years & 44 & $17.9 \%$ \\
\hline & Above 50 years & 4 & $1.6 \%$ \\
\hline \multirow{4}{*}{ Job Title } & Manager & 39 & $15.9 \%$ \\
\hline & Audit partners & 93 & 37.9 \\
\hline & Audit seniors & 114 & 46.2 \\
\hline & Other & 0 & 0 \\
\hline \multirow{3}{*}{$\begin{array}{c}\text { Academic } \\
\text { Qualification }\end{array}$} & Bachelor & 166 & $67.5 \%$ \\
\hline & Master & 74 & $30.1 \%$ \\
\hline & $\mathrm{PhD}$ & 6 & $2.4 \%$ \\
\hline \multirow{4}{*}{$\begin{array}{c}\text { Years of } \\
\text { experience in } \\
\text { Audit }\end{array}$} & $\begin{array}{c}\text { Less than } 5 \\
\text { years }\end{array}$ & 63 & $25.6 \%$ \\
\hline & $\begin{array}{c}\text { From } 5 \text { to } 10 \\
\text { years }\end{array}$ & 143 & $58.1 \%$ \\
\hline & $\begin{array}{c}\text { From } 10 \text { to } 15 \\
\text { years }\end{array}$ & 32 & $13 \%$ \\
\hline & $\begin{array}{c}\text { More than } 15 \\
\text { years }\end{array}$ & 8 & $3.2 \%$ \\
\hline
\end{tabular}

Descriptive statistics of the respondents: The results in Table 2 show that the majority of the auditors are female (by $61.8 \%$ ). It is suggested that the auditing profession is dominated by female. All members of the study sample have bachelor's degree and $32.5 \%$ of them hold higher certificates such as ACCA. The respondents fall in the age of 30-39 (50.8\%) and they have more than 5 years' experience. This finding indicates that most audit firms employ young professionals or have been in operation for a short period. Of the 246 participants, audit seniors account for $46.2 \%$, audit partners is $37.9 \%$, and managers is $15.9 \%$. The characteristics of the respondents reveal that they have attained Bachelor degree and Certified Public Accountants
(CPA) qualification with $58 \%$ which means that we can trust the answers of the study sample.

Descriptive statistics for variables: To regression analysis, it is required that the data is normally distributed with no multicollinearity among variables (Hair, Black, Babin, \& Anderson, 2009). A test of normality assumption was performed by using both Kurtosis and Skewness of data. The results show that the values are ranged between 0.735 to 0.290 for Kurtosis, and between -0.352 and 0.004 for Skewness. These values are belong to $[-1 ; 1]$ which suggests that the data is normally distributed and allows the regression test to be carried out (Hair, Black, Babin, \& Anderson, 2009).

Cronbach Alpha Coefficients are used to test factors affecting to RBAA adoption. In general, Cronbach Alpha coefficients of these factors are greater than 0.6, and correlation coefficients between variable are greater than 0.3 showing that the reliability of scale is ensured. Moreover, reliable testing of the 4 scales in RBAA adoption, the similar results are showed. According to the results in Table 3, KMO value is by $0.892 €[0.5 ; 1]$ and Sig. value of Bartletts's Test is by 0.000 (less than 0.05 ). Therefore, the application of exploratory factor analysis is appropriate.

Table 3: KMO and Bartlett's Test

\begin{tabular}{|c|c|c|}
\hline \multicolumn{2}{|c|}{$\begin{array}{c}\text { Kaiser-Meyer-Olkin Measure of Sampling } \\
\text { Adequacy }\end{array}$} & .892 \\
\hline \multirow{3}{*}{$\begin{array}{l}\text { Bartlett's Test of } \\
\text { Sphericity }\end{array}$} & Approx. Chi-Square & 7443.670 \\
\hline & $\mathrm{df}$ & 465 \\
\hline & Sig. & .000 \\
\hline
\end{tabular}

Appendix 1 demonstrates the explanation of the factors and the number of factors extracted. Factors are retained in the model when eigenvalue of factors is higher than 1 . There are 6 factors extracted. The Cumulative \% value of 76,523 shows that the first six factors explain $76.523 \%$ of variation in observed variables.

In Rotated Component Matrix (Table 4), the result findings determine the number of observed variables in each factor. According to Hair, Black, Babin, and Anderson (2009), the factors have practical significance when Factor loading is greater than 0.5 . Therefore, 31 observed variables are satisfied because of factor loading greater than 0.5. These observed variables are divided into 6 factors.

Additionally, test of correlation is used to test the degree of relationships between six factors and RBAA adoption. The results indicated that all factors have significant and positive correlation with RBAA adoption. In which, 4 factors including AABI, MOTI, ITEC, AFEE are the greatest. Sig value of the test is of $0.000(<0.05)$ which show that these variables are used in the regression model.

The study uses the regression analysis to test the model. The results in Table 5 showed that the model is suitable 
because adjusted $\mathrm{R}^{2}$ coefficient is high and Sig. value in Ftest is less than $0.05(\mathrm{Sig}=0.000)$. Adjusted $\mathrm{R}^{2}$ is of 0.749 , indicating that $74.9 \%$ of the variation of RBAA adoption is explained by 6 factors.

Table 4: Rotated component matrix

\begin{tabular}{|l|c|c|c|c|c|c|}
\hline & \multicolumn{5}{|c|}{ Component } \\
\hline & $\mathbf{1}$ & $\mathbf{2}$ & $\mathbf{3}$ & $\mathbf{4}$ & $\mathbf{5}$ & $\mathbf{6}$ \\
\hline ITEC7 & .860 & & & & & \\
\hline ITEC3 & .838 & & & & & \\
\hline ITEC2 & .826 & & & & & \\
\hline ITEC4 & .820 & & & & & \\
\hline ITEC6 & .820 & & & & & \\
\hline ITEC5 & .815 & & & & & \\
\hline ITEC1 & .752 & & & & & \\
\hline MOTI4 & & .829 & & & & \\
\hline MOT13 & & .820 & & & & \\
\hline MOTI6 & & .815 & & & & \\
\hline MOTI7 & & .813 & & & & \\
\hline MOT15 & & .699 & & & & \\
\hline MOTI1 & & .598 & & & & \\
\hline MOT12 & & .561 & & & & \\
\hline RISK2 & & & .875 & & & \\
\hline RISK5 & & & .861 & & & \\
\hline RISK4 & & & .821 & & & \\
\hline RISK1 & & & .681 & & & \\
\hline RISK3 & & & .644 & & & \\
\hline TIME3 & & & & .899 & & \\
\hline TIME1 & & & & .886 & & \\
\hline TIME4 & & & & .838 & & \\
\hline TIME2 & & & & .833 & & \\
\hline AFEE1 & & & & & .836 & \\
\hline AFEE2 & & & & & .791 & \\
\hline AFEE4 & & & & & .786 & \\
\hline AFEE3 & & & & & .731 & \\
\hline AABI2 & & & & & & .793 \\
\hline AABI4 & & & & & & .769 \\
\hline AABI1 & & & & & & .729 \\
\hline AABI3 & & & & & & .666 \\
\hline & & & & & & \\
\hline
\end{tabular}

Durbin-Watson is by 1.82 indicating that there is no autocorrelation in the dependent variable. Sig. value of Ftest is less than 0.05 which points out that the model is properly specified to reflect the effect of independent variables on the dependent variable.

Table 5: Suitable test of model

\begin{tabular}{|c|c|c|c|c|c|}
\hline Model & R & R Square & $\begin{array}{c}\text { Adjusted R } \\
\text { Square }\end{array}$ & $\begin{array}{c}\text { Std. Error } \\
\text { of the } \\
\text { Estimate }\end{array}$ & $\begin{array}{c}\text { Durbin- } \\
\text { Watson }\end{array}$ \\
\hline 1 & $.869^{\mathrm{a}}$ & .756 & .749 & .27627 & 1.828 \\
\hline \multicolumn{4}{|c|}{ a. Predictors: (Constant), MOTI, TIME, AFEE, RISK, ITEC, AABI } \\
\hline
\end{tabular}

All six factors have significant and positive relationships (at 5\% significant level) on the RBAA adoption (Table 6). Of which, auditor's ability to adopting
RBAA is the strongest factor with standardized coefficients by 0.391 while client's risk is the weakest (0.098). Finally, values of Variance Inflation Factor (VIF) are low for all independent variables showing the absence of multicollinearity problem.

Table 6: Regression results of model

\begin{tabular}{|c|c|c|c|c|c|c|c|}
\hline \multirow{2}{*}{ Model } & \multicolumn{2}{|c|}{$\begin{array}{c}\text { Unstandardized } \\
\text { Coefficients }\end{array}$} & \multirow{2}{*}{ St. Co. } & \multirow{2}{*}{ t } & \multirow{2}{*}{ Sig. } & \multicolumn{2}{|c|}{$\begin{array}{c}\text { Collinearity } \\
\text { Statistics }\end{array}$} \\
\cline { 2 - 5 } & $\mathbf{B}$ & $\begin{array}{c}\text { Std. } \\
\text { Error }\end{array}$ & Beta & & & Tolerance & VIF \\
\hline Constant & -.546 & .177 & & -3.081 & .002 & & \\
\hline AABI & .404 & .046 & .391 & 8.787 & .000 & .517 & 1.933 \\
\hline ITEC & .204 & .042 & .204 & 4.840 & .000 & .577 & 1.733 \\
\hline AFEE & .159 & .041 & .159 & 3.913 & .000 & .620 & 1.613 \\
\hline TIME & .120 & .030 & .143 & 3.971 & .000 & .788 & 1.269 \\
\hline RISK & .093 & .039 & .098 & 2.395 & .017 & .614 & 1.630 \\
\hline MOTI & .151 & .048 & .153 & 3.168 & .002 & .441 & 1.267 \\
\hline
\end{tabular}

St. Co.: Standardized Coefficients

\section{Conclusion}

The study aimed at exploring how independent audit firms in Viet Nam understand the risk based audit approach. The objectives were guided by research questions including: the motivations of auditing firms to adopt RBAA; the advantages and disadvantages of RBAA; and factors influence the RBAA adoption in independent audit firm in Vietnam. In terms of the motivations, there seem to have conflicting opinions about the motivation for adopting RBAA between Big 4 auditors and Non-Big 4 auditors. According to Big 4 auditors, benefits of RBAA and the general trend of the world were great motivation to implement RBAA. While, almost Non-Big 4 auditors explained that changes in regulations force them to adopt RBAA. In general, responses about advantages of adopting RBAA were the same between two groups of audit firms. These advantages include: improve audit efficiency and quality, provide aware of problems and concerns of clients, increase client and user confidence in financial report and provide added value to the clients. These views concur with previous studies (Cullinan \& Sutton, 2002; Knechel, 2007; Lemon, Tatum, \& Turley, 2000; Peecher, Schwartz, \& Solomon, 2007).

In terms of the disadvantages, it seems that the disadvantages of adopting RBAA are mainly proposed by Non-Big 4 auditors. These restrictions consist of high audit fees, lack of relevant knowledge, lack of experience, lack of proper tools to identify risks, lack of relevant guidelines, and complexity of RBAA. About the level of adopting RBAA in audit practice, the results of this study show that RBAA is used to a moderate extent in Vietnam. However, the RBAA is practiced by audit firms to different extents. If Big 4 audit firms apply the RBAA to a high degree, Non- 
Big 4 audit firms apply the RBAA to a low degree. The results are in the line with the studies of Naibei, Oima, and Ojera (2014b) but contrasts with the study of Kutum, Fraser, and Hussainey (2015).

The main reason for this problem is differences in customer characteristics and audit fees depend largely on the role of international auditing firms. This finding is supported by previous studies (Abdullatif \& Al-Khadash, 2010; Bell, Solomon, \& Thomas, 1997). Efforts include focusing on client's risk assessment such as governance systems, critical business processes, strategies and goals of client. Many risk assessments do not yield favorable results because they rarely affect major audit plan and decisions making. The auditors are not convinced that extended risk assessments under RBAA are necessary. There are several reasons such as low audit fees, audit time to explain why they do not want to change old audit methods in order to expand the audit efforts (Sandra \& Patrick, 1996).

About factors influencing on adopting RBAA, based on Regression model, there are six factors influencing RBAA adoption consist of Auditor's ability to adopting BRAA, Technological development, Audit fees, Motivation to adopting BRAA, Audit time and Client's risk. Of which, Auditor's ability, and technological development are factors that have the most significant and positive impacts on the RBAA adoption. This shows that the learning mechanism and improving knowledge about auditing and information technology are the minimum requirement for auditors. However, in addition to the efforts of auditors, it is necessary to involve stakeholders. In particular, government agencies and professional associations play a vital role in fostering and maintaining the competence of auditors through the issuance of guiding documents and opening professional courses.

Audit firms play a crucial role in facilitating and motivating auditors by equipping information technology as well as funding to participate in audit courses. Motivation to adopt BRAA, audit fee, and audit time have positive relationships with the application of RBAA. General recommendation is that small audit firms should focus on expansion strategies such as merging with other small firms. This will improve the audit fees, competitive advantage and attract bigger clients. Client's risk also has positive impact on the RBAA adoption. However, the effect is not significant. As mentioned above, most audit firm's clients are small and medium size. These companies have poor corporate governance systems and internal control. Therefore, auditors often assess that client's risk always exist with high level. They have ignored control test and increased the level of substantive test. The research findings are line with Abdullatif and Al-Khadash (2010); Kutum, Fraser, and Hussainey (2015).

\section{References}

Abdallah, A. A. J., Mssadeh, A. A. D., \& Othman, O. H. (2015). Measuring the impact of business risks on the quality of the auditing process. Review of Integrative Business Economics Research, 4(2), 171-181.

Abdullah, K. A., \& Al-Araj, S. R. (2011). Traditional Audit versus Business Risk Audit: A Comparative Study Case of Jordan. European Journal of Economics, Finance and Administrative Sciences, 40, 74-91.

Abdullatif, M., \& Al-Khadash, H. (2010). Putting audit approaches in context: The case of business risk audits in Jordan. International Journal of Auditing, 14(1), 1-24. doi: 10.1111/j.1099 1123.2009.00400.x

Aldjaafarh, M. (2008). How keen the audit offices to provide requirements to improve the effectiveness of the external audit in Jordanian public shareholding companies (Master thesis). Amman, Jordan: University of the Middle East.

Allaham, T., Nassar, A. M., \& Reesh, S. A. (2017). Factors affecting the application of business risk audit methodology in Jordanian commercial banks. International Journal of Business and Social Science, 8(7), 229-236.

Arens, A. A., Elder, R. J., \& Beasley, M. S. (2010), Auditing and Assurance Services: An Integrated Approach (12th ed.). Englewood Cliffs, NJ: Prentice Hall.

Bell, T. B., Marrs, F. O., Solomon, I., \& Thomas, I. (1997). Auditing Organizations through a Strategic Systems Lens. KPMG, Montvale, NJ. Retrieved August 25, 2018, from http://www.business.illinois.edu/kpmguiuccases/monograph.PDF

Bell, T. B., \& Solomon, I. (2002). Cases in StrategicSystems Auditing: KPMG and University of Illinois at Urbana-Champain Business Measurement Case Development and Research Program. Montvale, NJ: KPMG. Retrieved August 25, 2018, from http://www.business.illinois.edu/kpmguiuccases/casebo ok.pdf

Choy, A. K., \& King, R. R. (2005). An experimental investigation of approaches to audit decision making: an evaluation using systems-mediated mental models. Contemporary Accounting Research, 22(2), 311-350. doi: 10.2139/ssrn.337681

Cullinan, C. P., \& Sutton, S. G. (2002). Defrauding the public interest: a critical examination of reengineered audit processes and the likelihood of detecting fraud. Critical Perspectives on Accounting, 13, 297-310. doi: 10.1006/cpac.2001.0527

Curtis, E., \& Turley, S. (2007). The business risk audit: a longitudinal case study of an audit engagement. Accounting, Organizations and Society, 32, 439-61. doi: 10.1016/j.aos.2006.09.004 
Gibson, M. S. (2003). Is corporate governance ineffective in emerging markets? Journal of Financial and Quantitative Analysis, 38(1), 231-250. doi: $10.2307 / 4126771$

Hair, J. F., Black, W. C., Babin, B. J., \& Anderson, R. E. (2009). Multivariate Data Analysis (7th ed.). Upper Saddle River, NJ: Prentice Hall International.

Knechel, W. R. (2001). Auditing: assurance and risk (2nd ed.). Cincinnati, OH: South-Western College Publishing.

Knechel, W. R. (2007). The business risk audit: Origins, obstacles and opportunities. Accounting, Organizations and Society, 32, 383-408. doi: 10.1016/j.aos.2006.09.005

Kutum, I., Fraser, I., \& Hussainey, K. (2015). The application of business risk audit methodology within Non-Big 4 firms. Journal of Financial Reporting and Accounting, 13(2), 226-246. doi: 10.1108/JFRA-032014-0015

Lemon, W. M., Tatum, K. W., \& Turley, W. S. (2000). Developments in the audit methodologies of large accounting firms. London, UK: ABG Publications.

Lovaas, P. (2009). A comprehensive risk-based Auditing framework for Small and Medium Sized financial institutions. Issues in information Systems, 10(2), 485495.

Mozammal, M. (2005, November). Risk-based Audit: Lessons from Kenya Pilot. Operations Policy and Country Services (No. 9). Retrieved September 15, 2018, from http://siteresources.worldbank.org

Naibei, K. I., Oima, D. O., \& Ojera, P. B. (2014a). Moderating effect of business risk on the audit fee model among small audit firms: Case of Western region, Kenya. European Scientific Journal, 10(10), 445-462. doi: 10.19044/esj.2014.v10n10p\%25p

Naibei, K. I., Oima, D. O., \& Ojera, P. B. (2014b). Application of Business Risk Auditing among Audit Firms in Western Region, Kenya. An International Multidisciplinary Journal, Ethiopia, 8(2), 325-342. doi: 10.4314/afrrev.v8i2.19
Nazmi, E., Arori, I. M. S., \& Ibrahim, M. R. (2017). The factors affect business risk audit and their impact on the external auditing quality in Jordanian commercial banks (Case study). European Journal of Accounting, Auditing and Finance Research, 5(5), 1-17

Nguyen, T. M. A., \& Le, T. T. (2018). Auditing financial statements in insurance enterprises: The case of Vietnam. Management Science Letters, 9, 313-324. doi: 10.5267/j.msl.2018.11.009.

Peecher, M. E., Schwartz, R., \& Solomon, I. (2007). It's all about audit quality: perspectives on strategic-systems auditing. Accounting, Organizations and Society, 32, 463-85. doi: 10.1016/j.aos.2006.09.001

Prinsloo, J. (2008). Development and evaluation of riskbased audit approaches (Doctoral dissertation). Bloemfontein, South Africa: University of Free State.

Robson, K., Humphery, C., Khalifa, R., \& Jones, J. (2007). Transforming audit technologies: business risk audit methodologies and the audit field. Accounting, Organizations and Society, 32, 409-438. doi: 10.1016/j.aos.2006.09.002

Sardasht, M. S., \& Rashedi, E. (2018). Identifying Influencing Factors of Audit Risk Model: A Combined Fuzzy ANP-DEMATEL Approach. The International Journal of Digital Accounting Research, 18, 69-117. doi: 10.4192/1577-8517-v18_4

Sandra, W. M. H., \& Patrick, P. H. N. (1996). The determinants of audit fees in Hong Kong: an empirical study. Asian review of Accounting, 4, 31-50. doi: 10.1108/eb060673

Vilsanoiu, D., \& Serban, M. (2010). Changing Methodologies in Financial Audit and their Impact on Transforming Systems Audit. Informatica Economica, 14(1), 57-65.

Winograd, B. N., Gerson, J. S., \& Berlin, B. L. (2000). Audit practices of PricewaterhouseCoopers. Auditing: A Journal of Practice and Theory, 19(2), 175-182. doi: 10.2308/aud.2000.19.2.176 
Appendix 1: Total variance explained

\begin{tabular}{|c|c|c|c|c|c|c|c|}
\hline & Total & \% of Variance & Cumulative \% & Total & \% of Variance & Cumulative \% & Total \\
\hline 1 & 13.058 & 42.121 & 42.121 & 13.058 & 42.121 & 42.121 & 5.683 \\
\hline 2 & 3.113 & 10.042 & 52.163 & 3.113 & 10.042 & 52.163 & 4.840 \\
\hline 3 & 2.539 & 8.191 & 60.354 & 2.539 & 8.191 & 60.354 & 3.732 \\
\hline 4 & 1.986 & 6.407 & 66.761 & 1.986 & 6.407 & 66.761 & 3.464 \\
\hline 5 & 1.874 & 6.046 & 72.807 & 1.874 & 6.046 & 72.807 & 3.048 \\
\hline 6 & 1.152 & 3.716 & 76.523 & 1.152 & 3.716 & 76.523 & 2.957 \\
\hline 7 & .769 & 2.480 & 82.119 & & & & \\
\hline 8 & .591 & 1.907 & 84.025 & & & & \\
\hline 9 & .534 & 1.722 & 85.748 & & & & \\
\hline 10 & .495 & 1.597 & 87.345 & & & & \\
\hline 11 & .434 & 1.400 & 88.745 & & & & \\
\hline 12 & .362 & 1.166 & 89.912 & & & & \\
\hline 13 & .347 & 1.119 & 91.031 & & & & \\
\hline 14 & .293 & .944 & 91.974 & & & \\
\hline 15 & .302 & .975 & 92.020 & & & \\
\end{tabular}

